\title{
SERUM IODINE IN HYPOTHYROIDISM BEFORE AND DURING THYROID THERAPY ${ }^{1,2}$
}

\author{
By ALEXANDER W. WINKLER, DOUGLAS S. RIGGS, AND EVELYN B. MAN \\ (From the Departments of Internal Medicine and Psychiatry of Yale University, School of Medicine, \\ and the Medical Service of New Haven Hospital and Dispensary, New Haven, Connecticut; \\ and the Laboratory of the Fairfield State Hospital, Newtown, Connecticut)
}

\section{(Received for publication March 19, 1945)}

Many investigations have established the value of serum iodine concentration as a quantitative index of thyroid activity ( 1 to 7 ). Most previous reports have been concerned primarily with the increase in serum iodine which occurs in hyperthyroidism. The present study deals with the decrease in serum iodine characteristic of untreated hypothyroidism, and with the effect of thyroid therapy on the level of serum iodine of hypothyroid patients.

\section{MATERIAL}

Data are presented on 29 patients with spontaneous hypothyroidism and 1 patient (84883) with hypothyroidism following total thyroidectomy. Most of the patients were ambulatory. The majority have been studied in the Metabolism Clinic of the New Haven Hospital, many of them having been followed there for a period of several years. Two patients (F.S.H. 4774 and F.S.H. 4924) were observed at the Fairfield State Hospital. The remainder were private patients. In order to keep the group as homogeneous as possible, no patients have been included in whom the diagnosis of hypothyroidism was questionable or who developed hypothyroidism following subtotal thyroidectomy. In most of the patients included here the diagnosis of hypothyroidism was confirmed by striking improvement in signs and symptoms after a few weeks of thyroid therapy. In the few patients who remained untreated, or who were inadequately treated, the diagnosis rested on the presence of the clinical manifestations of hypothyroidism. Most of the patients did not present the extreme clinical picture usually described as typical of full-blown, classical myxedema. For example, generalized non-pitting edema was extremely rare. While most patients at some time during the course of their disease did exhibit some puffiness of the face, in a few even this slight degree of edema was never observed. It is reasonable to suppose, therefore, that many of the patients probably had small remnants of functional thy-

1 This investigation was aided by a grant from the Fluid Research Funds of the Yale University School of Medicine.

2 A preliminary report of this work has appeared in the Proceedings of the American Society for Clinical Investigation in the Journal of Clinical Investigation, 1944, 23, 931. roid tissue which prevented them from developing fullblown myxedema. The left portion of Table I summarizes the clinical findings in these patients when the sign and symptoms of hypothyroidism were most outspoken. In certain patients thyroid therapy was stopped in order to confirm the need for its administration; such a procedure is indicated in the column "Days off Thyroid." It should be emphasized that the heart rates and basal metabolic rates recorded under the heading "Maximal Signs and Symptoms" are the lowest observed while the patient was receiving no thyroid. Since the basal metabolism could only be determined once or twice before thyroid therapy was begun, it is not certain that a completely "basal" level was always obtained. The average heart rates and basal metabolic rates off thyroid medication would tend to be somewhat higher.

Serum cholesterol and serum iodine from blood of patients in the post-absorptive state were determined by methods previously described $(2,8,9,10)$. The majority of iodine determinations were done on serum. Some figures, however, represent protein bound iodine as determined on serum proteins precipitated with zinc sulfate and sodium hydroxide (serum precipitable iodine) (2). Such values have been marked in the tables by the superscript P. Provided there has been no unusual intake of iodine, values for serum iodine and for serum precipitable iodine do not differ significantly. A few figures for serum iodine, indicated by the superscript $B$ in the tables have been calculated from determinations of whole blood iodine by assuming that the cells contained no iodine and that the relative cell volume was 40 per cent (11). Barring unusual iodine intake, these assumptions are reasonably accurate, and the calculated values are comparable to values for serum iodine directly determined.

Since the amount of iodine in the serum of myxedematous patients is exceedingly small, some discussion of the accuracy of serum iodine determinations is necessary if the results are to be evaluated correctly. When duplicate $6 \mathrm{ml}$. aliquots of serum have been analyzed, the duplicates have usually checked within 0.5 gamma per cent. If the duplicates differed by more than 0.9 gamma per cent, the analysis was considered unsatisfactory and, if possible, was repeated. It is evident that if the concentration of serum iodine is below normal the possible analytical error represents a large proportion of the determined value. Hence, small differences in the results of determinations on the same patient at different times 


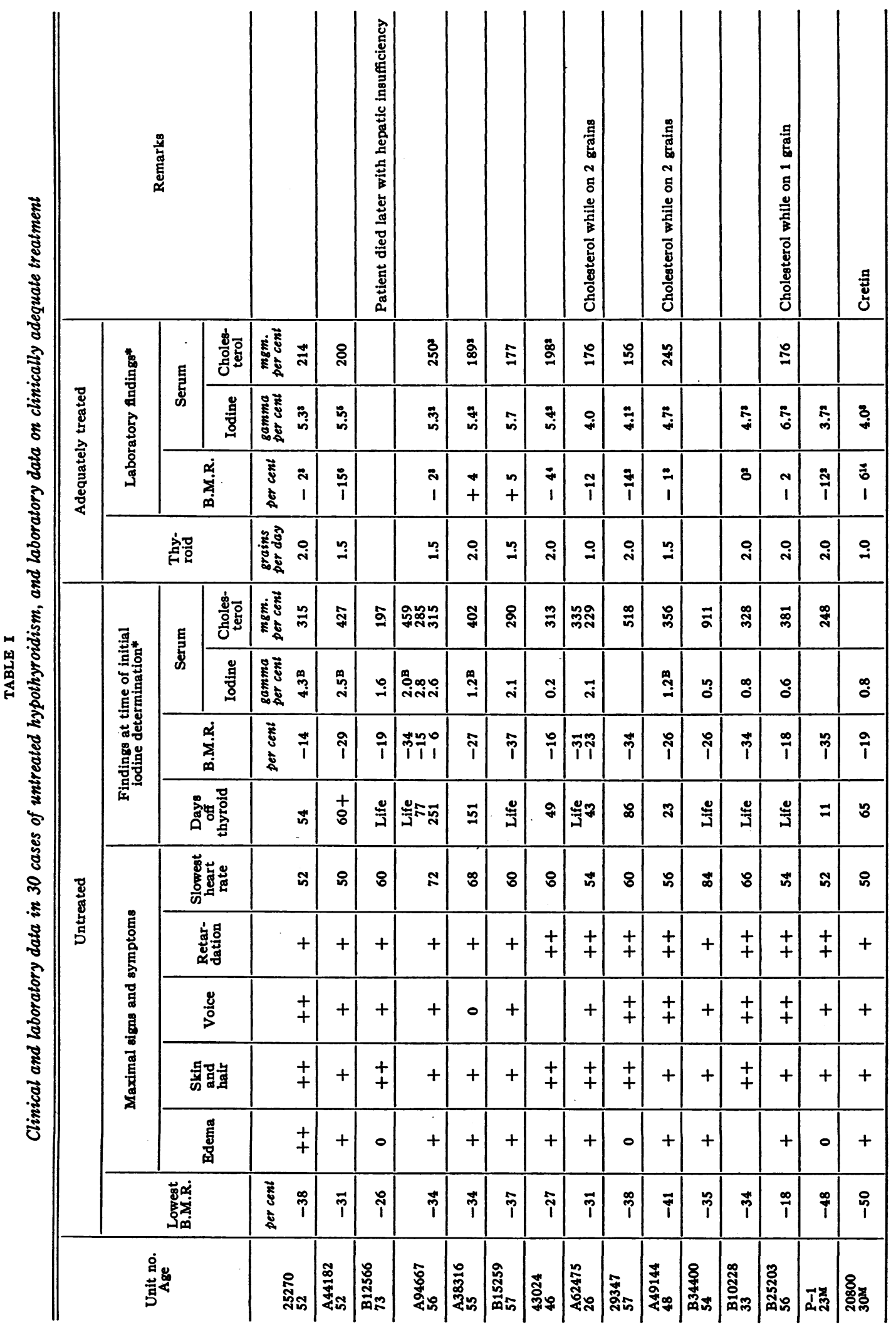




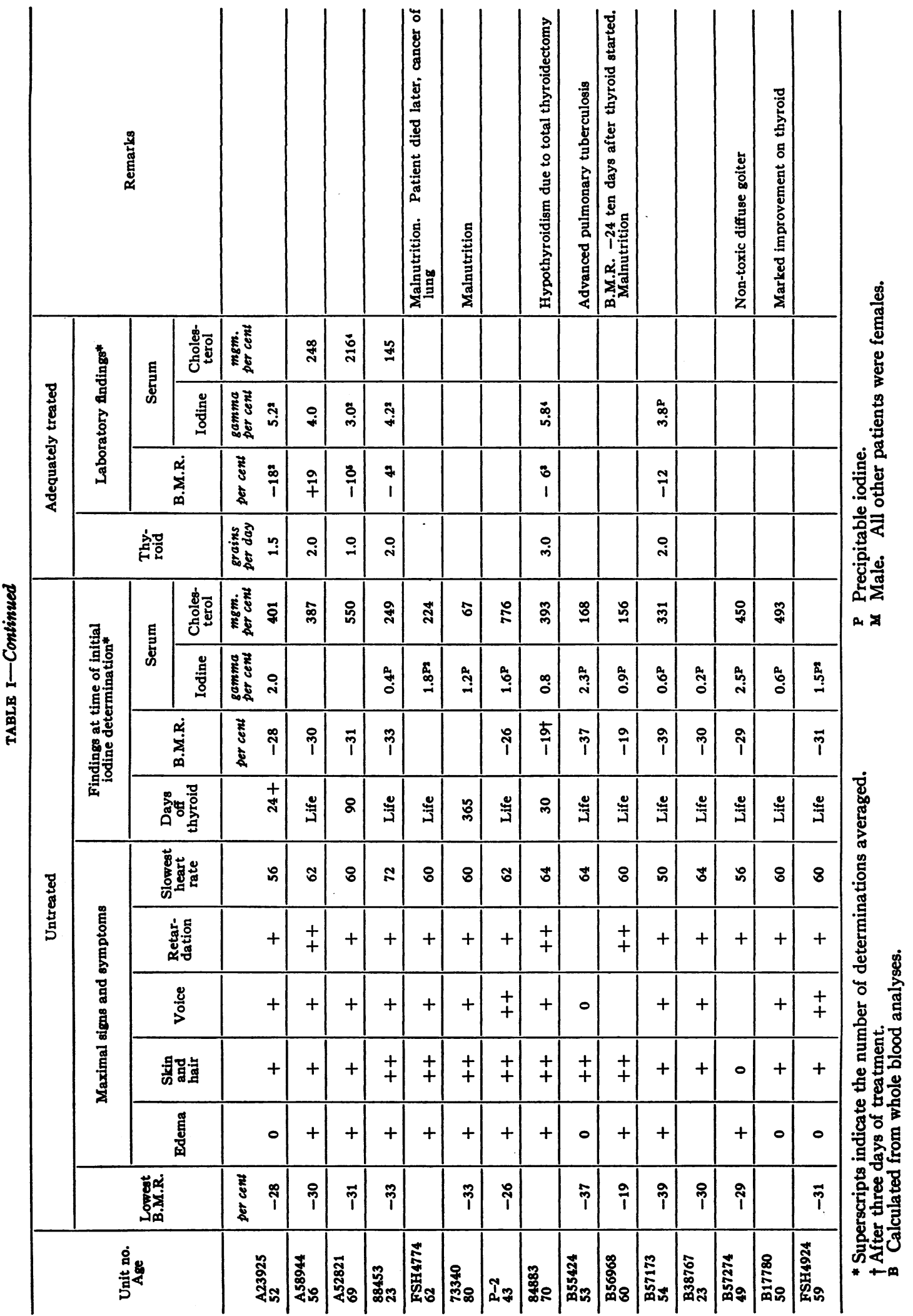


are of no significance, unless such differences are found consistently and repeatedly.

The basal metabolic rates were determined with the Benedict-Roth apparatus under the standard conditions described by Benedict, DuBois and others.

\section{RESULTS}

Serum iodine in untreated hypothyroidism. Serum iodine was determined in 26 of the patients before therapy with desiccated thyroid was begun, or after a lapse in treatment of at least 23 days' duration. With 1 exception (25270) all of the figures were well below the extreme normal range of 3.0 to 9.0 gamma per cent. ${ }^{3}$ Omitting this exception, the arithmetical mean was 1.3 gamma per cent, the range being from 0.2 to 2.5 gamma per cent. With the single exception noted above (25270) the basal metabolic rates were below -15 per cent when the serum iodine was determined (Table I). In 6 of the patients, however, the metabolism was but slightly substandard, from -16 to -19 per cent. This apparent discrepancy between the level of circulating thyroid hormone and the metabolic rate will be discussed below.

Serum iodine in hypothyroid patients adequately treated with desiccated thyroid. Nineteen of the patients were studied while taking an amount of desiccated thyroid sufficient to maintain them in what appeared clinically to be normal thyroid status (Table I). The maintenance dose requirement varied from 1 to 3 grains per day, and was most commonly $1 \frac{1}{2}$ or 2 grains per day. Under adequate treatment the serum iodine rose to normal, ranging from 3.0 to 6.7 gamma per cent and averaging 4.8 gamma per cent. In most of the patients the basal metabolic rate was also within normal limits at the time of the serum iodine determination.

The relationship between thyroid dose and serum iodine. Table II presents data on the serum iodine of all' patients who were studied on at least 2 levels of medication. In a few cases it was possible to vary the dose experimentally in order to study the effect on serum iodine. In

3 Although most normal serum iodine values fall within the range of 4.0 to 8.0 gamma per cent, some patients without clinical evidence of thyroid disease have serum iodine concentrations as low as 3.0 or as high as 9.0 gamma per cent (12).
TABLE II

Serum iodine in hypothyroid subjects stabilized on various doses of U.S.P. thyroid

\begin{tabular}{|c|c|c|c|c|c|c|}
\hline \multirow{3}{*}{$\begin{array}{l}\text { Unit } \\
\text { no. }\end{array}$} & \multicolumn{5}{|c|}{$\begin{array}{l}\text { Concentration of iodine in serum of } \\
\text { hypothyroid patients } * x\end{array}$} & \multirow{3}{*}{$\begin{array}{l}\text { Average* } \\
\text { increase in } \\
\text { serum iodine } \\
\text { per grain } \\
\text { of thyroid }\end{array}$} \\
\hline & \multicolumn{5}{|c|}{ Grains of U.S.P. thyroid per day } & \\
\hline & $\mathbf{0}$ & 1.0 & 1.5 & 2.0 & 3.0 & \\
\hline \multirow[t]{2}{*}{$\begin{array}{l}\text { A44182 } \\
\text { A38316 } \\
\text { B25203 } \\
20800 \\
\text { A23925 } \\
88453 \\
\text { A49144 } \\
84883^{* *} \\
25270 \\
\text { A94667 } \\
\text { B15259 } \\
43024 \\
\text { B10228 } \\
\text { A62475 } \\
\text { B57173 } \\
\text { B34400 } \\
\text { B12566 } \\
29347 \\
\text { P-1 } \\
\text { A58944 } \\
\text { A52821 }\end{array}$} & $\begin{array}{c}\text { gamma } \\
\text { per } \\
\text { cent } \\
2.5^{\mathrm{B}} \\
1.2 \mathrm{~B} \\
0.6 \\
0.8 \\
2.0 \\
0.4 \mathrm{P} \\
1.2^{\mathrm{B}} \\
0.6^{2 \mathrm{P}} \\
4.3^{\mathrm{B}} \\
2.5^{3} \\
2.1 \\
0.2 \\
0.8 \\
2.1 \\
0.6^{\mathrm{P}} \\
0.5 \\
1.6\end{array}$ & $\begin{array}{c}\text { gamma } \\
\text { per } \\
\text { cent } \\
\\
2.9^{2} \\
4.2^{2} \\
4.0^{8} \\
4.2^{2} \\
2.9 \\
3.4^{P} \\
5.4^{3}\end{array}$ & $\begin{array}{c}\text { gamma } \\
\text { per } \\
\text { cent } \\
5.5^{5} \\
4.0 \\
\\
5.2^{2} \\
4.7^{3} \\
\\
5.3^{2} \\
5.7\end{array}$ & $\begin{array}{c}\text { gamma } \\
\text { per } \\
\text { cent } t \\
6.8 \\
5.4^{2} \\
6.7^{3} \\
4.1 \\
7.8 \\
3.7^{2} \\
3.7 \mathrm{~B} \\
4.9 \mathrm{P} \\
5.3^{3} \\
\\
5.4^{2} \\
4.7^{3} \\
\\
3.8^{2} \mathrm{P} \\
4.3^{2 \times x} \\
4.1^{2} \\
3.7^{2} \\
4.0\end{array}$ & $\begin{array}{l}6.1^{7 P} \\
6.9^{4}\end{array}$ & $\begin{array}{c}\text { gamma } \\
\text { per } \\
\text { cent } \\
2.2 \\
2.1 \\
3.0 \\
1.6 \\
2.9 \\
1.6 \\
1.2 \\
1.8 \\
(0.5) \\
1.9 \\
2.4 \\
2.2 \\
2.0 \\
1.9 \\
1.6\end{array}$ \\
\hline & \multicolumn{5}{|c|}{ Average (omitting 25270) } & $2.0 \pm 0.13$ \\
\hline
\end{tabular}

$\times$ Superscripts indicate number of determinations averaged.

* Calculated from minimum and maximum values.

** Determinations omitted in which dose was not stabilized for 2 weeks, except when otherwise indicated.

B Calculated from whole blood analyses.

$P$ Precipitable iodine.

- On one grain only 7 days.

$x \times$ On two grains only 8 days.

$\infty \times$ Value of 2.1 while on 3 grains omitted.

( ) Indicates doubtful value.

other patients the dose was changed from time to time as the clinical status of the patient demanded.

In 15 of the patients it has been possible to study the change in serum iodine as the dosage varied between 0 and one or more definite levels of thyroid dosage, each level of dosage having been maintained for at least 2 weeks prior to the iodine determination. For these patients values for the average increase in serum iodine per grain of thyroid have been calculated over the maximum range, from zero grains to the highest dosage level, neglecting any intermediate figures (Table II). The increase in serum iodine per grain of thyroid in hypothyroid patients was remarkably constant. The arithmetical mean was 2.0 gamma per cent 
per grain of thyroid with a standard deviation of \pm 0.5 gamma per cent and a standard error of the mean of \pm 0.13 gamma per cent. ${ }^{4}$ One value of 0.5 gamma per cent (patient 25270) has been omitted from the average for reasons to be discussed presently.

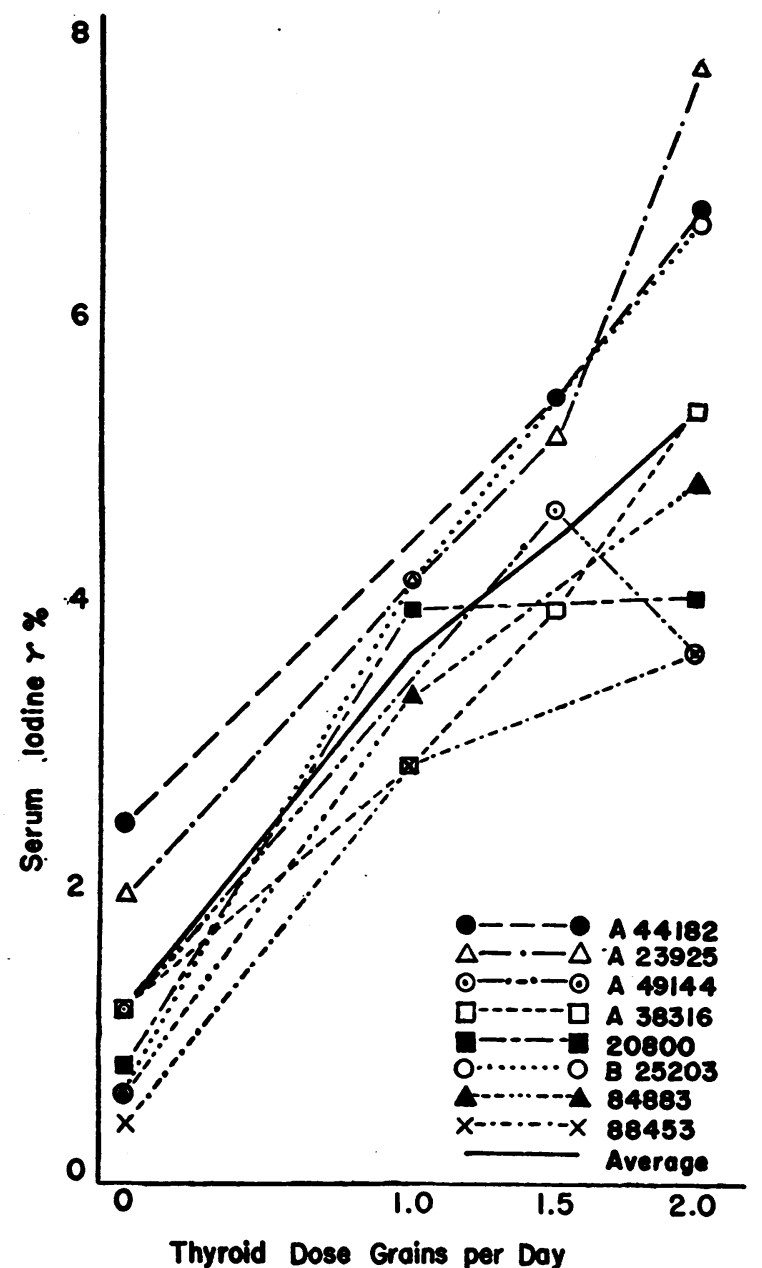

Fig. 1. Average Serum Iodine Concentrations in the 8 Patients of Table II

These patients were at one time or another maintained without thyroid, on a dosage of 2 grains daily and on at least 1 intermediate dosage. The data from the other 4 patients of Table II who were maintained on three levels of dosage (A94667, 43024, 29347, and A58944) are omitted since the lack of data at one or another of these 3 levels necessitated their exclusion in the calculation of the average.

$$
\begin{aligned}
& \text { 4 Standard deviation } \quad=s=\sqrt{\frac{\epsilon(x-x)^{2}}{N-1}} \\
& \text { Standard error of the mean }=s_{x}=\frac{s}{\sqrt{N}}
\end{aligned}
$$

The first 8 patients of Table II were studied while on 0 grains daily, 2 grains daily, and at least 1 intermediate dose of thyroid. In Figure 1 , the serum iodine values for these patients have been plotted against the daily dose of thyroid. While there is considerable individual variation, the upward trend of serum iodine as the dose was increased is apparent. The solid line is drawn through the average values at $0,1,11 / 2$ and 2 grains. Not all patients were studied both on 1 grain and on $1 \frac{1}{2}$ grains of thyroid daily. In averaging the serum iodine values for these levels, therefore, it was necessary to calculate some figures by interpolation. The inclusion of these calculated figures necessarily tends to make the average curve artificially linear. Despite this slight bias, and despite the somewhat steeper slope of the average line from 0 to 1 grain per day than from 1 to 2 grains per day, the distribution of points suggests that the average curve cannot be reliably distinguished from a straight line.

Serum cholesterol values before and during treatment. Serum cholesterol was determined in 27 of these patients at a time when no thyroid was being administered (Table I). Twenty exhibited the hypercholesterolemia characteristic of hypothyroidism (13), the values ranging from 290 to 911 milligrams per cent. Of the 7 remaining patients with cholesterol levels below 265 milligrams per cent, $1(\mathrm{P}-1)$ had been off thyroid for only 11 days. There remain 6 patients with low or normal serum cholesterol values, the significance of which will be discussed later.

Serum cholesterol determinations were repeated in 13 of the patients after adequate treatment with desiccated thyroid had been instituted (Table I). Without exception, the hypercholesterolemia was abolished, the final values falling well within the normal range of 123 to 265 milligrams per cent (14).

\section{DISCUSSION}

Most of the early workers on blood iodine levels in hypothyroidism employed inadequate analytical techniques and their results are not considered here. Since the advent of more reliable methods for iodine estimation, a few reports of serum iodine in untreated hypothyroidism have appeared (Table III), but none of these have included any discussion of the effects of thyroid 
TABLE III

Published values on serum iodine in hypothyroidism

\begin{tabular}{|c|c|c|c|c|c|c|}
\hline \multirow{2}{*}{ Investigator } & \multirow{2}{*}{$\begin{array}{c}\text { Num- } \\
\text { ber } \\
\text { of } \\
\text { cases }\end{array}$} & \multicolumn{3}{|c|}{ Serum iodine } & \multirow{2}{*}{$\begin{array}{l}\text { Normal } \\
\text { range }\end{array}$} & \multirow{2}{*}{ Comment } \\
\hline & & $\underset{\text { mumi- }}{\text { Maxi- }}$ & $\begin{array}{l}\text { Mini- } \\
\text { mum }\end{array}$ & Mean & & \\
\hline $\begin{array}{l}\text { Turner, DeLamater and } \\
\text { Province (15) }\end{array}$ & 5 & $\begin{array}{c}\text { gamma } \\
\text { per } \\
\text { cent } \\
\\
9.7\end{array}$ & $\begin{array}{c}\text { gamma } \\
\text { pert } \\
\text { cent } \\
1.5\end{array}$ & $\begin{array}{c}\text { gamma } \\
\text { pert } \\
\text { cent } \\
\\
5.8\end{array}$ & 6.7 to 16.7 & Calculated from whole blood \\
\hline $\begin{array}{l}\text { Riggs, Gildea, Man and } \\
\text { Peters (1) }\end{array}$ & 7 & 2.8 & 0.5 & & 4.0 to 7.0 & Calculated from whole blood \\
\hline $\begin{array}{l}\text { Salter, Bassett and } \\
\text { Sappington (4) }\end{array}$ & 20 & 3.9 & 0.8 & 2.5 & 4.0 to 8.0 & Serum precipitable iodine \\
\hline \multirow{2}{*}{$\begin{array}{l}\text { Talbot, Butler, Saltzman and } \\
\text { Rodriguez (6) }\end{array}$} & 1 & & & 3.8 & 6.0 to 8.4 & Serum precipitable iodine-adults \\
\hline & 4 & 3.0 & 1.8 & 2.3 & 4.0 to 7.0 & Serum precipitable iodine-children \\
\hline Present series & 30 & 4.3 & 0.2 & $1.3^{*}$ & 3.0 to 9.0 & \\
\hline
\end{tabular}

* Value of 4.3 excluded from mean. This omission is discussed in the text.

therapy on the level of serum iodine. With the exception of Turner and co-workers (15), all of these investigators have found that serum iodine values in untreated hypothyroidism are uniformly subnormal. This conclusion is abundantly confirmed by the series reported here (Table I). The 1 exception (25270) was a patient who had been on thyroid for 17 years and whose treatment was allowed to lapse in order to confirm the original diagnosis of hypothyroidism. After nearly 2 months without thyroid the patient experienced such a marked exacerbation of her symptoms as to necessitate resumption of therapy. At this time, however, the laboratory data were not in good accord with the clinical picture. The basal metabolic rate was only -14 per cent. The bound magnesium was 21 per cent of the serum total magnesium, well within normal limits (16). There was a slight hypercholesterolemia. In view of these findings it seems possible that the patient, fully aware of the efficacy of thyroid, may have resumed treatment herself a few days before her visit to the clinic. This would explain the normal iodine of 4.3 gamma per cent. An alternative explanation might be contamination of the blood sample with adventitious iodine before or during analysis, since the determination was not on the precipitated proteins. In any event, this single exception does not seriously challenge the conclusion that in untreated hypothyroidism, serum iodine is characteristically subnormal, just as it is characteristically above normal in hyperthyroidism. Failure to find a low serum iodine in a patient suspected of having hypothyroidism strongly suggests that the patient's symptoms are not due to thyroid deficiency.

It should be emphasized that a single subnormal serum iodine value is not diagnostic of hypothyroidism. Equally small concentrations of iodine have been found in the blood of euthyroid subjects who have recently stopped taking large amounts of desiccated thyroid (17), and of hyperthyroid patients following subtotal thyroidectomy (12). By itself, therefore, a low serum iodine simply indicates undersecretion by the thyroid gland when the blood sample was collected, and it must be interpreted in the light of the patient's symptoms and previous history.

It has already been suggested that few of the patients reported here were completely devoid of functional thyroid tissue. However in 1 patient (84883) known to have had a total thyroidectomy, serum iodine values not significantly greater than 0 were observed. Furthermore, treatment of hyperthyroid patients with thiouracil or thiourea in amounts sufficient to occasion symptoms of hypothyroidism may lower the concentration of serum precipitable iodine to the vanishing point (18). Total lack of thyroid secretion for a sufficient period of time would therefore appear to imply 
virtual absence of circulating thyroid hormone, and grave doubt is cast on the existence in man of significant extrathyroidal manufacture of thyroid hormone. Of 17 patients in the present series who had been untreated for 1 year or more, 9 had serum iodine concentrations above 1.0 gamma per cent, i.e., significantly greater than 0 . The appearance of symptoms of hypothyroidism, therefore, does not necessarily imply complete absence of thyroid function.

The rise in serum iodine to normal levels when hypothyroid patients were treated with adequate doses of desiccated thyroid is in accordance with the well-established fact that relatively small daily doses of thyroid are sufficient to maintain subjects without thyroid tissue in normal thyroid balance. It also agrees with the hypothesis that, barring unusual sources of exogenous iodine, serum iodine is a reliable measure of the concentration of circulating thyroid hormone. Moreover, since the serum iodine levels in adequatelytreated patients with hypothyroidism are no higher than in euthyroid individuals, the circulating hormone derived from substitution therapy with desiccated thyroid must be quantitatively as effective as the hormone produced by the normally active thyroid gland. It seems legitimate to conclude that the maintenance dose of thyroid required by any patient with hypothyroidism is that amount which will restore the serum iodine to normal.

The effect on serum iodine of administration of various amounts of desiccated thyroid has already been noted (Table II and Figure 1). Since the figures for increase in serum iodine per grain of desiccated thyroid were calculated from the difference between 2 iodine values, they were subject to twice the possible error of a single determination. In view of the large possible analytical error, the constancy of the increase in serum iodine per grain of desiccated thyroid is particularly remarkable. In obtaining the average value of 2.0 gamma per cent of iodine per grain of thyroid, the data on patient 25270 were omitted. As stated previously, there was reason to doubt the normal value obtained on this patient when she was supposedly receiving no thyroid.

The amount of hormone supplied by the normally-functioning thyroid gland has usually been considered as equivalent to the maintenance dose of desiccated thyroid for hypothyroid patients.
This hypothesis involves 3 assumptions: that all the dried thyroid is absorbed from the alimentary tract; that it is quantitatively as effective as the natural hormone; and lastly, that the hypothyroid patient's own gland contributes no hormone. Although complete intestinal absorption has not been proved directly, it is strongly suggested by the fact that in the treatment of human hypothyroidism, desiccated thyroid is even more effective than intravenous thyroxine in iodoequivalent amounts (19). The validity of the second assumption has already been discussed. The third assumption is not always justified since a patient with outspoken clinical hypothyroidism may have a serum iodine concentration of 1.0 to 2.0 gamma per cent. However, since each grain of dried thyroid causes an increase in serum iodine averaging 2.0 gamma per cent, even in the complete absence of endogenous hormone production, 3 grains of desiccated thyroid per day should result in a final serum iodine concentration of about 6.0 gamma per cent, a value close to the average normal level. The production of hormone by the normal thyroid gland may therefore be regarded as approximately equivalent, in terms of iodine content, to 3 grains of U.S.P. desiccated thyroid.

If each additional grain of thyroid administered to a hypothyroid subject causes a rise in serum iodine of about 2.0 gamma per cent, it is easy to understand why such patients are unable to tolerate more than 3 grains of thyroid daily without developing definite symptoms of thyroid excess such as nervousness, tremor, and tachycardia. If the initial serum iodine of thyroid were 1.3 gamma per cent (the average for this series of patients), and 4 grains of thyroid per day were administered, the serum iodine would presumably rise to about 9.3 gamma per cent, a value distinctly above the normal range. This calculation involves the unproven assumption that the linear relationship between dose and serum iodine would hold for doses greater than 2 grains per day. Nevertheless, the result of the calculation agrees with clinical observation that slight over-doses of thyroid are prone to induce high serum iodine levels and unpleasant symptoms of hyperthyroidism in previously hypothyroid subjects.

The average relationship between serum iodine and basal metabolic rate may be roughly evaluated. The effect of varying thyroid dose on the basal 


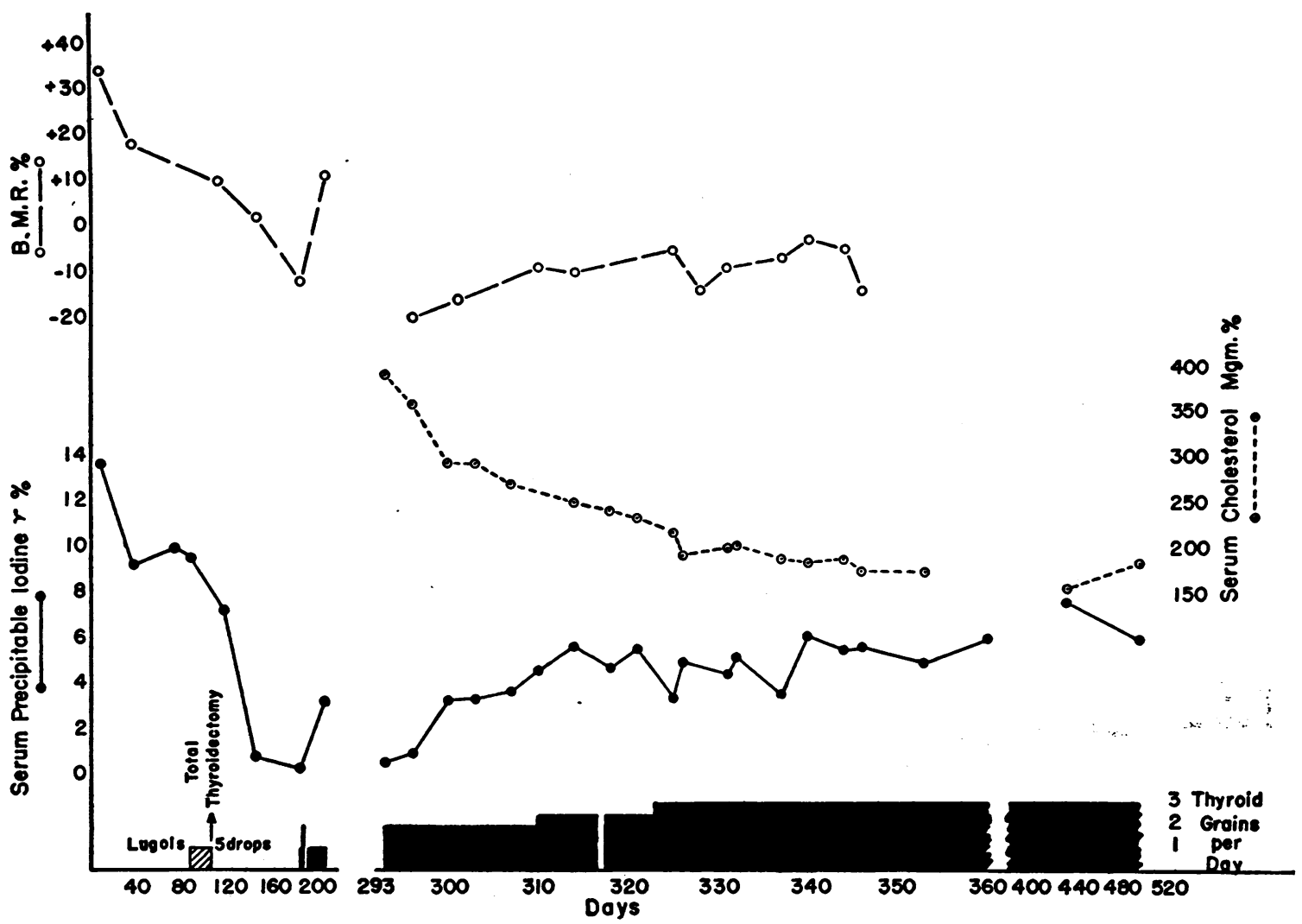

Fig. 2. Changes in Basal Metabolic Rate, Serum Precipitable Iodine and Serum Cholesterol in a Hyperthyroid Patient Subjected to Total Thyromectomy

The elevated initial basal metabolism and serum iodine confirmed the diagnosis of moderately severe hyperthyroidism. Forty days after operation the serum iodine had already fallen to 1.0 gamma per cent, yet the metabolic rate was still +3 per cent. Thirty-eight days later the serum iodine was 0.5 gamma per cent-scarcely distinguishable from 0 , while the patient was exhibiting signs and symptoms of hypothyroidism. Nevertheless the basal metabolic rate at this time had only decreased slightly, to -11 per cent. Following a brief course of thyroid therapy, the patient failed to return to the clinic for almost 3 months, during which time she took little or no thyroid. When seen again 6 months following operation the serum iodine was 0.8 gamma per cent and the serum cholesterol almost $400 \mathrm{mgm}$. per cent. Symptoms of hypothyroidism were outspoken. Unfortunately a determination of basal metabolic rate was not done until 3 days after treatment with thyroid was begun, at which time it was -19 per cent. The changes following the institution of therapy appear in the figure. Note the changes in the time-scale.

metabolic rate in hypothyroidism was analyzed and these workers (20) concluded that, for the range of 0 to 2 grains daily, the true dose-response curve was probably much closer to a straight line than to the curvilinear relationship suggested by other investigators (21). The former found that the basal metabolism increases about 12 to 16 per cent per grain of desiccated thyroid. Comparison with the slope of the average line of Figure 1 yields a value for the increase in basal metabolic rate of 6 or 8 per cent per gamma per cent increase in serum iodine. The relationship holds only for values obtained after a given dosage had been maintained for several weeks without change. The metabolic rate responds much more slowly to alterations in thyroid status than does the serum iodine. In support of this statement, Figure 2 presents in detail the laboratory data on a hyperthyroid patient who developed hypothyroidism following total thyroidectomy. It is apparent that in this case the decrease in serum iodine following total extirpation of the thyroid gland was out of all proportion to the change in basal metabolism. In several additional cases the 
basal metabolic rate has remained relatively high despite a definitely subnormal concentration of iodine in the blood serum. For example patient A94667, when first seen, had a basal metabolic rate of -34 per cent and a serum iodine of 2.0 gamma per cent. After more than a year of satisfactory treatment with thyroid, medication was discontinued for 251 days. During this time the basal metabolism never fell below - 15 per cent, and after the 251 days without treatment was only -6 per cent. Yet serum iodine values of 2.8 gamma per cent and 2.6 gamma per cent were found 77 and 251 days after thyroid therapy was stopped. These values were almost as low as the initial one when the metabolic rate was frankly subnormal. Indeed, in the entire series of patients at the time of the initial iodine determination metabolic rates as low as -30 per cent or lower need not appear unless the patient had remained untreated for several years (Table I, columns 8 and 9). Yet in at least 3 instances (43024, A62475, and A49144) the serum iodine fell to low concentrations when thyroid had been omitted for less than 2 months. Similar dissociation between metabolic rate and blood iodine has been observed after subtotal thyroidectomy (12) and following discontinuance of thyroid medication in euthyroid subjects (17). It is not possible to state from our data exactly how rapidly the serum iodine decreases after thyroid has been stopped but it is clear that the decrease may take place weeks or even months before there is any marked change in the basal metabolism. Whether this lag is due to retention of active hormone in the tissues, or whether the fall in metabolism is dependent on slowly-occurring changes which are secondary to the diminished amount of active hormone in the body, cannot be stated until more is known concerning the mode of action of the thyroid hormone. In any event, it would appear that fluctuation in the level of serum iodine in hypothyroidism corresponds more nearly to the need of thyroid therapy than does the basal metabolic rate.

The previous reports in which some earlier articles were cited have emphasized the constancy of hypercholesterolemia in untreated hypothyroidism $(13,22)$. In the present series the incidence of normal or subnormal serum cholesterol values, in patients untreated for a reasonably long period of time, was unusually high (24 per cent). Of the 6 patients who did not develop hypercholesterolemia (B12566, 88453, F.S.H. 4774, B55424, B56968, and 73340), 3 were suffering from severe malnutrition, 1 died soon afterwards with advanced hepatic insufficiency, 1 had active pulmonary tuberculosis, and 1 was without obvious complications. Both malnutrition and advanced hepatic insufficiency are known to be associated with depression of the serum cholesterol (23, 24, 25). Hypercholesterolemia is not, therefore, an obligatory accompaniment of hypothyroidism, and, in the presence of nutritional deficiency or advanced liver disease, the serum cholesterol level may be normal or even exceedingly low (73340).

\section{SUMMARY AND CONCLUSIONS}

1. In untreated hypothyroidism serum iodine is characteristically subnormal. In many hypothyroid patients, however, it is significantly greater than 0 , indicating the presence of some functional thyroid tissue in such patients.

2. Desiccated thyroid in amounts sufficient to relieve the symptoms of hypothyroidism causes a return of serum iodine to normal levels.

3. On the average, a 1-grain increase in the daily dose of thyroid administered to hypothyroid subjects occasions an increase in serum iodine of 2.0 gamma per cent. The relationship between serum iodine and thyroid dose appears to be linear within the limits of 0 and 2 grains per day.

4. The basal metabolic rate responds much more slowly to alterations in thyroid status than does the serum iodine.

5. Evidence is presented in support of the hypothesis that, in terms of iodine content, the daily production of hormone by the normally functioning thyroid gland is roughly equivalent to 3 grains of U.S.P. desiccated thyroid.

6. It is concluded that serum iodine is not only a valuable aid in the diagnosis of hypothyroidism but is also a useful criterion of the adequacy of treatment with thyroid substance.

\section{BIBLIOGRAPHY}

1. Riggs, D. S., Gildea, E. F., Man, E. B., and Peters, J. P., Blood iodine in patients with thyroid disease. J. Clin. Invest., 1941, 20, 345.

2. Man, E. B., Smirnow, A. E.; Gildea, E. F., and Peters, J. P., Serum iodine fractions in hyperthyroidism. J. Clin. Invest., 1942, 21, 773. 
3. Bassett, A. M., Coons, A. H., and Salter, W. T., Protein-bound iodine in blood. V. Naturally occurring iodine fractions and their chemical behavior. Am. J. M. Sc., 1941, 202, 516.

4. Salter, W. T., Bassett, A. M., and Sappington, T. S., Protein-bound iodine in blood. VI. Its relation to thyroid function in 100 clinical cases. Am. J. M. Sc., 1941, $202,527$.

5. Klassen, K. P., Bierbaum, R. L., and Curtis, G. M., The comparative iodine content of whole blood and serum. J. Lab. and Clin. Med., 1940, 26, 365.

6. Talbot, N. B., Butler, A. M., Saltzman, A. H., and Rodriguez, P. M., The colorimetric estimation of protein-bound serum iodine. J. Biol. Chem., 1944, 153, 479.

7. Lowenstein, B. E., Bruger, M., and Hinton, J. W., The protein-bound plasma iodine in patients with thyroid disease. I. Correlation with basal heat production. J. Clin. Endocrinol., 1944, 4, 268.

8. Man, E. B., and Peters, J. P., Gravimetric determination of serum cholesterol adapted to the Man and Gildea fatty acid method with a note on the estimation of lipoid phosphorus. J. Biol. Chem., 1933, 101, 685.

9. Bogdanovitch, S. B., and Man, E. B., The effect of castration, theelin, testosterone, and antuitrin-S on the lipoids of blood, liver, and muscle of guinea pigs. Am. J. Physiol., 1938, 122, 73.

10. Riggs, D. S., and Man, E. B., A permanganate acid ashing micromethod for iodine determinations. I. Values in blood of normal subjects. J. Biol. Chem., 1940, 134, 193.

11. Riggs, D. S., Lavietes, P. H., and Man, E. B., Investigations on the nature of blood iodine. $\mathrm{J}$. Biol. Chem., 1942, 143, 363.

12. Man, E. B., and Winkler, A. W., Unpublished data.

13. Gildea, E. F., Man, E. B., and Peters, J. P., Serum lipoids and proteins in hypothyroidism. J. Clin. Invest., 1939, 18, 739.
14. Peters, J. P., and Man, E. B., The interrelations of serum lipids in normal persons. J. Clin. Invest., 1943, $22,707$.

15. Turner, K. B., DeLamater, A., and Province, W. D., Observations on the blood iodine. I. The blood iodine in health, in thyroid and cardiorenal disease, and in leukemia. J. Clin. Invest., 1940, 19, 515.

16. Dine, R. F., and Lavietes, P. H., Serum magnesium in thyroid disease. J. Clin. Invest., 1942, 21, 781.

17. Riggs, D. S., Man, E. B., and Winkler, A. W., Serum iodine of euthyroid subjects treated with desiccated thyroid. J. Clin. Invest., 1945, 24, 722.

18. Danowski, T. S., Winkler, A. W., and Man, E. B., Treatment of hyperthyroidism with a combination of iodine, thiourea in small doses, and desiccated thyroid. To be published in the Am. J. M. Sc.

19. Means, J. H., Lerman, J., and Salter, W. T., The rôle of thyroxine iodine and total organic iodine in the calorigenic action of whole thyroid gland. J. Clin. Invest., 1933, 12, 683.

20. Winkler, A. W., Criscuolo, J., and Lavietes, P. H., Quantitative relationship between basal metabolic rate and thyroid dosage in patients with true myxedema. J. Clin. Invest., 1943, 22, 531.

21. Means, J. H., and Lerman, J., Symptomatology of myxedema: Its relation to metabolic levels, time intervals and rations of thyroid. Arch. Int. Med., 1935, 55, 1.

22. Peters, J. P., and Man, E. B., The interrelations of serum lipids in patients with thyroid disease. $\mathrm{J}$. Clin. Invest., 1943, 22, 715.

23. Man, E. B., and Gildea, E. F., Serum lipids in malnutrition. J. Clin. Invest., 1936, 15, 203.

24. Hodges, R. G., Sperry, W. M., and Andersen, D. H., Serum cholesterol values for infants and children. Am. J. Dis. Child., 1943, 65, 858.

25. Man, E. B., Kartin, B. L., Durlacher, S. H., and Peters, J. P., The lipids of serum and liver in patients with hepatic disease. J. Clin. Invest., 1945, $24,623$. 